UDC

\title{
THE BACHKA-SREM RUSIN ANIMAL IDIOMS AND THEIR ENGLISH EQUIVALENTS*
}

\author{
M. Feysa \\ Novi Sad University \\ 2 Dr. Zoran Dyindyich Street, Novi Sad, 21000, Serbia \\ E-mail: fejsam@gmail.com
}

\begin{abstract}
The paper deals with the analysis of the Bachka-Srem Rusin animal idioms and their English counterparts. The author provides an overview of Rusin animal idioms as used in Rusin dictionaries and distinguishes their English counterparts as used in English dictionaries. There are three distinctive groups of names: those included on both languages, different animal or no animal at all in the English counterpart. These three kinds of counterparts are clearly marked in the paper which is useful to systematize Rusin phraseology and to find the English equivalents. Generally speaking, the paper aims at observing the way in which the meanings of the Bachka-Srem Rusin animal idioms are conveyed by the idioms of the English language.
\end{abstract}

Keywords: animal idioms, Rusin language, English language, translation equivalents, contrastive analysis.

\footnotetext{
* The paper is part of Projects Nr. 187002 (Languages and Cultures In Time and Space) and Nr. 187017 (Discourses of Minority Languages, Literatures and Cultures In Southeast and Central Europe) supported by the Ministry of Education, Science and Technological Development of the Republic of Serbia.
} 


\title{
БАЧКО-СРЕМСКИЕ РУСИНСКИЕ \\ АНИМАЛИСТИЧЕСКИЕ ИДИОМЫ \\ И ИХ АНГЛИЙСКИЕ ЭКВИВАЛЕНТЫ
}

\author{
М. Фейса \\ Университет г. Новый Сад \\ Сербия, 21000, ул. 3. Диндича, 2 \\ E-mail: fejsam@gmail.com
}

\section{Авторское резюме}

Анализируются анималистические идиомы в бачко-сремском русинском языке и их английские эквиваленты. С одной стороны, приведен обзор идиом с названиями животных в русинском языке, которые содержатся в словарях русинов, с другой стороны, показаны их отличия от английских эквивалентов, которые используются в английских словарях. Три группы эквивалентов четко обозначены в статье, которая будет полезна для систематизации русинской фразеологии и поиска английских эквивалентов. Целью этой статьи является наблюдение за тем, как значения анималистических идиом русинов Бачки и Срима передаются идиомами английского языка.

Ключевые слова: анималистические идиомы, русинский язык, английский язык, переводные эквиваленты, контрастный анализ.

\section{Introduction}

David Crystal writes that the year 2000 marked the end of a decade in which linguistic revolution took place. He also emphasizes that dramatic linguistic changes do not happen very often. The emergence of new media such as newspapers, telephone and television also led to linguistic change, but the impact of the Internet can certainly be described as revolutionary (Crystal 2001). What makes the language of the Internet linguistically unique is its combination of written and spoken language characteristics. Naomi Baron uses a metaphor to describe this new form of language and names it a "linguistic centaur half speech, half writing" (Baron 2001: 248).

Young members of the Rusin community, being members of a national minority, are aware that they should use at least three languages: the state language (Serbian), the mother tongue (Rusin) and the global language (English) (Feysa 1990, Feysa 2010). The use of English as a 
lingua franca and as a learner language implies a growing familiarity with the English language. Much of English communication, both professional and private, takes place all over the world between nonnative speakers. One of the most difficult parts of a language to learn is phraseology. This research is aimed to help the Rusins to systematize Rusin phraseology and to find the English equivalents to the Rusin ones. We are aware that we can not fully express ourselves or understand others if we do not know the most common phraseologisms. The term phraseologism was introduced in linguistics of the Bachka-Srem Rusins by Yuliyan Ramach (2002: 456). As its synonym we will use the term idiom in this paper (according to: Varga, Groszler 2008; Ivanovska, Groszler 2011). Idiom is a succession of words (terms, phrases or sentences) which is stable in its structure and meaning. Its meaning is not obvious through knowledge of the individual meanings of the constituent words but must be learnt as a whole. Idiom meaning has been created through common use for decades or for centuries.

The research corpus has mainly been formed on the basis of two lexicographic works - two-volume Serbian-Rusin Dictionary (Ramach et al. 1995; Ramach et al. 1997) and Rusin-Serbian Dictionary (Ramach et al. 2010). The corpus consists of 190 Rusin idioms. Their equivalents have been established on the basis of the following dictionaries: two-volume encyclopedic An English-Serbocroat Dictionary (Ristich et al. 1974), Serbocroation-English Dictionary (Benson 1977) and Oxford Advanced Learner 's Dictionary of Current English (Hornby 1977). In establishing equivalency we are close to Werner Koller who considered that equivalence deals with equivalent items in specific ST-TT (source text - target text) pairs and contexts and that it is possible to distinguish "five different types of equivalence: (a) denotative equivalence involving the extralinguistic content of a text,(b) connotative equivalence relating to lexical choices, (c) text-normative equivalence relating to text-types, (d) pragmatic equivalence involving the receiver of the text or message, and, finally, (e) formal equivalence relating to the form and aesthetics of the text" (Koller 1979:186-191; Baker, Saldahna 2011:96-97; according to Panou 2013: 4).

After establishing semantic equivalency we have compared Rusin animal idioms and their English counterparts. We have distinguished three kinds of English counterparts: a) English idioms that include the same animal names as the ones in Rusin idioms (they are underlined in the following chapter); b) English idioms with different animal names than the ones in Rusin idioms (they are italicized in the following chapter); c) English equivalents without animal names (they are not marked). 
Generally speaking, the purpose of this paper is to observe the way in which the meanings of the Bachka-Srem Rusin animal idioms are conveyed by the idioms of the English language.

\section{Rusin Animal Idioms and Their English Counterparts}

\section{AHNETS - ahnets Bozhi: The Lamb of God (Jesus Christ).}

BARAN - nabrats (navishats, natrepats) na sebe yak baran na rohi: to take too many obligations (literally: as a ram on its horns); lapits barana: to be covered with mud (literally: as after catching a ram).

BIYALA - motsni yak biyala: as strong as a bull (literally: as strong as a buffalo).

BARANCHE - vovk u baranchetsovey skori: a wolf in a lamb`s skin; mirni yak baranche: to be very quiet (literally: as a lamb).

BUBA - ma bubu u hlavi: to have a bee in one s' bonnet (literally: he has a bug in his head); voshli mu bubi do hlavi: to be nuts (crazy); buts mirni yak buba: to be very quiet.

BUYAK - hvatsits buyaka za rohi: to take the bull by the horns; yak buyak na chervene napadats: to attack (literally: as when a bull attacks something red); richits (drets she) yak buyak: cry loudly (literally as a bull); von nye mozhe baylagovats z buyakom: he can not control it (literally: a bull).

TSELYE - piyani yak tselye: as drunk as a fish, as drunk as a billed owl (literally: as drunk as a calf); patrits yak celye na novu kapuru: like a dying pig in a thunderstorm (literally: looking like a calf at a new gate; to be completely baffled); umilne tselye (tselyatko) dva kravi tsitsa: he plays both sides (literally: a sweet calf sucks two cows); piyani yak tselye: very drunk (literally: as drunk as a calf); yak tselye pri tsitski: to attach to somebody (as a calf to cow's udder); i krava starsha a tselyetsu rits lyizhe: sometimes old people must respect youth (literally: a cow is older but it licks a calf's rear); ked poshla krava nay idze i tselye: when we gave so much money let's give a little more (literally: when a cow went away let a calf go away as well).

HAD - noshits hada u pershokh: to shelter somebody who turns out to be ungrateful; sichats yak had: to use bad language; ists hadovi do piskokh, stanuts hadovi na khvost: to get into trouble.

HOLUB - lyepshe tashchok u ruki yak holub na dreve: a bird in the hand is worth two in the bush (literally: a bird in the hand is better than a pigeon in the tree).

HUSKA - yak na husku voda, yak ked na husku vodi plyushnye: he has no influence on anyone (literally: as water on a goose); nye za huski sheno (bo ho roztsahayu): it is not for you (literally: hay is not for geese). 
HUSHE - bezhits yak hushe za yahodu: unrestrainably run (literally: as a gosling to mulberry fruit).

KHROBAK - mats khrobaka u hlavi: to have a bee in one s' bonnet (literally: he has a worm in his head).

YAHNYATKO - zhertvene yahnyatko: sacrificial lamb; vovk u yahnyatkovey skori: a wolf in a lamb`s skin

KACHE - bridke kache: ugly duckling; zmoknuti yak kache: to get drenched (literally: as a duckling); bezhits yak kache (kachata) za yahodu: unrestrainably run to do something usually bad (literally: as a duckling to mulberry fruit); nye za kachata machanka: it is not for you (literally: sauce is not for ducklings).

KANDUR - patrits (pazherits she) yak kandur na kolbasi (slanyinu): his mouth is watering (literally: as tomcat's mouth to sausages or bacon); dali kandurovi kolbasi chuvats: they made a mistake (literally: they let a tomcat to guard sausages); khodzits yak kandur kolo kolbasokh: to walk around all the time (literally: as a tomcat around sausages).

KACHKA - pravi she zlata kachka: to be nice only in special occasions (literally: pretends to be a golden duck).

KON` - robits yak kon`: to work like a horse; darovanomu kon 'ovi she nye patri do zubokh: do not look a gift horse in the mouth; troyanski kon': Troyan horse; buts na kon'u (kon'ove): be successful (literally: to be on a horse); spadnuts z kon`a na magartsa (osla): out of the frying pan into the fire (or: to be moved down to a lower rank; literally: as from horseback to donkeyback); to anyi kon 'nye mozhe vitrimats: that's more than flesh and blood can stand (literally: that can not be endured even by a horse); virobeni yak kon': worn-out (literally: as a horse); von nye mozhe baylagovats z kon 'om: he can not control it (literally: he can not ride a horse).

KOZA - i koza sita i kapusta tsala: everyone is satisfied (literally: both the goat is full and the cabbage has not been touched).

KRAVA - krava: cow ("stupid, clumsy woman"); umilne celye (celyatko) dva kravi tsitsa: he plays both sides (literally: a sweet calf sucks two cows); ya nye krava za doyenye: I am not made of money (literally: I am not a cow to be milked); i charna krava dava bile mlyeko: it is all the same (literally: a black cow also gives white milk); dobra zhena yak tota krava tso do polnoho zhokhtara virgnye: she only seems to be a good woman (literally: she is as a good woman as the cow that spills milked milk); i krava starsha a tselyetsu rits lyizhe: sometimes old people must respect youth (literally: a cow is older but it licks a calf's rear); ked poshla krava nay idze i tselye: when we gave so much money let's give a little more (literally: when a cow went away let a calf go away as well); nye stoyi tsi krava na nohi: be more patient (literally: a cow does not stand 
on your foot); nye chuval ya $z$ tobu kravi: we are not that close (or: we are not on an equal footing; literally: I did not watch over cows with you); shvechi tsi yak kravi shedlo: it does not become you (literally: it becomes you as a saddle becomes a cow); rozrutsats (roztrests) yak krava vihrizki: to make a mass (literally: as a cow after eating its food).

KROKODIL - krokodilski slizi: crocodile tears.

KURA - rozumi she yak kura do piva: he doesn 't understand anything (or: it is Greek to him; literally: he understands it as a hen understands beer); i shlyepey kuri she uydze zarno: sometimes even a person who has no qualifications (gift) for a job may be successful (literally: even a blind hen finds a grain); yomu kura a mnye vaytso: you gave the bigger and the better to him (literally: a hen to him and an egg to me); krutsi she yak kura z vaytsom: he walks around not knowing what to do (literally: as a hen with an egg); lyehats z kurami: to go to bed very early (literally: to lie down with hens); shedats yak kura na banti: to know when to withdraw (literally: to sit as a hen in its chicken house); od starey kuri lyepsha yushka: old wine is best (literally: the soup is better from an old hen).

KURCHE - zamervic she yak kurche do klocha: to get into a difficult situation (literally: like a chicken in tow); uchi kurche kvoku: he tries to explain something to someone who knows it better (literally: a chicken teaches a hen).

LASTOVKA - persha lastovka nye prinoshi yar: one swallow does not make spring.

LEBED - lebedova pisnya: swan song.

LYISHKA - hamishni (lukavi) yak lyishka: cunning (literally: as a fox).

LYEV - yak lyev: like a lion.

MAGARETS / OSEL - tvardohlavi yak magarets: as stubborn as a mule; pravits dakoho magartsom, pravits (robits) $z$ dakoho magartsa: to make a fool out of somebody (literally: to make a donkey out of somebody); stoyi yak magarets medzi ovtsami: stands and works nothing (literally: stands as a donkey among sheep); dats (cherats) konya za magartsa: to give a more valuable thing for a less valuable one (literally: to give a horse for a donkey); pravits z mukhi magartsa: to make a mountain out of a molehill (literally: to make a donkey out of a fly); spadnuts z konya na magartsa: out of the frying pan into the fire (or: to be moved down to a lower rank; literally: as from horseback to donkeyback); to anyi magarets nye mozhe vitrimats: that's more than flesh and blood can stand (literally: that can not be endured even by a donkey); stari yak stari magarets: very old (literally: as old as an old donkey).

MACHKA - ked machki nyet mishi po hizhi behayu: when the cat is away, the mice will play; vadza (skladayu) she yak pes i machka: to fight 
like cats and dogs; kupic mačku u mehu: to buy a pig in a poke (literally: to buy a cat in a sack); bavits she $z$ dakim yak machka z mishu (mishom): to play with somebody (literally: as a cat with mouse); ked tse machka nye preskochi: uncertain expectation (literally: if a cat does not jump over you).

MAYMUN - spravovats she yak maymun, virabyac yak maymun: to play the ape, to act like a monkey.

MEDVEDZ - zrobic dakomu medvedzhu usluhu: to do somebody a disservice (literally: to do somebody a bear's favour).

MAZGA - tvardohlavi yak mazga: as stubborn as a mule.

MISH / MISHA - ked machki nyet, mishi po hizhi behayu: when the cat is away, the mice will play; holi yak mish: to be as poor as a church mouse; zmoknuti jak miš / miša: to get drenched (literally: as a mouse); menshi od misha: very small (literally: smaller than a mouse); skrits she do mishovey dziri: to withdraw into a shell (literally: to hide in a mouse hole); tsikho ye yak mish u dziri: he is silent (literally: as a mouse in a mouse hole); nye vidno tse yak biloho misha: you can not be seen (literally: like a white mouse).

MUKHA - umerali (padali) yak mukhi: they died (dropped) like flies; zabits z yednim vderen om dva mukhi: to kill two birds with one stone (literally: to kill two flies with one blow); pravits z mukhi magartsa: to make a mountain out of a molehill (literally: to make a donkey out of a fly); zaplyests she yak mukha do pauchini: to get into a difficult situation (literally: like a fly in spider's web); lyipnyu she na nyu yak mukhi na med: many boys stick with her (literally: as flies to honey); znats od choho mukhi zdikhayu: he always finds a solution (literally: he knows what makes flies die); von zabiva mukhi: he works nothing (literally: he kills flies).

OSA - osovo (oshe) hnyizdo: wasp's nest, hornet 's nest; nye rushaj osovo (oshe) hnyizdo: let sleeping dogs lie (literally: do not touch wasp's nest).

OVTSA - charna ovtsa: black sheep; stratsena ovtsa: lost sheep; vovk u ovchey skori: a wolf in sheep's clothing; nye chuval ya z tobu ovtsi: we are not that close (or: we are not on an equal footing; literally: I did not tend sheep with you); zverits ovtsi vovkovi: to have no confidence in someone (literally: to commit sheep to wolf's care).

PAPAGAY - nauchits datso yak papagay: to learn something like a parrot.

PCHOLA - vredni yak pchol(k)a: a busy as a bee.

PES - yak pes na lantsu: like a chained dog; vadza (skladayu) she yak pes i machka: to fight like cats and dogs; rutsits psom: to throw to the dogs; pes khtori vel'o breshe, nye kusa: barking dogs don't bite; hladni yak pes: as hungry as a bear (literally: as a dog); znats od choho psi zdikhayu: he always finds a solution (literally: he knows what makes dogs die); to bi anyi pes na khvost nye pozberal: no one would swallow 
that story (literally: even a dog will not collect it with its tail); anyi bi ho pes nye prebrekhal: he talks too much (literally: a dog would not outbark him); anyi pes nye zbrekhnye na n ho: nobody will pay attention to him (literally: a dog would not bark at him); hrikh psa vihnats vonka: it is bad weather (literally: it is a sin to send a dog out of a house): virni yak pes: faithful (literally: as a dog); treba tsi to yak psu piyata noha: you do not need it (literally: you need it as a dog needs the fifth leg); zhits yak pes na pazdzerchu: to have a hard life (literally: to live like a dog on boon of flax); nabits dakoho yak psa: to beat up black-and-blue, to beat mercilessly (literally: to beat someone like a dog); nahnyival she yak babin pes: he got very angry (literally: he got angry as granny's dog); nye budze zoz psa slanyina: nothing will become of him (literally: you will never make bacon of a dog); nye ver psu anyi ked shpi: do not trust a bad man (literally: a dog even when it sleeps); pes psa pozna: a bad man recognizes another bad man easily (literally: a dog recognizes a dog); poysts yak pes z kostsu (pshim lyitsom): to go away discouraged (literally: to go away as a dog with a bone or with dog's face); pridze i na psa mraz, chekay pshe nye budze vshe tak: he will have bad days too (literally: frost will cause injuries to a dog as well; wait, dog, it will not be always like this); pushch psa pod stol vigrabe she na stol: ungrateful persons always want more (literally: When you let a dog go under the table it will get on the table); tsiganyi yak pes: he always lies (literally: he lies as a dog); shvechi yak psovi dzvonchok (piyata noha): that does not become him (literally: that becomes him like a bell or the fifth leg becomes a dog); khodzi yak kurti pes: he always looks for something (literally: he walks like a tailless dog).

PRASHE - yests yak prashe: to make a pig of oneself; nashey shvinyi prashe: our man (literally: our swine`s pig); buts trinaste prashe: to be unnecessary (literally: to be the thirteenth pig)

PREPILKA - yomu tuzok a mnye prepilku: you gave the bigger and the better to him (literally: a bustard to him and a quail to me).

PTITSA - ptitsa selyidbenyitsa: bird of passage; shpivats yak ptichka: to sing like a bird; уак ptitsa nyebesna: to do something like a bird; yak ptitsa na konare: like a fish in water (literally: like a bird on a branch); ptitsa she po piryu pozna: appearances tell (literally: one can recognize a bird by its feathers).

RIBA - vel'ka riba: big fish; drobna riba (ribka): small fish; yak riba na sukhim (na brehu): he is like a fish out of water; yak riba $u$ vodi: like a fish in water; buts tsikho yak riba: he is as quiet as a mouse (literally: be as quiet as fish); $u$ tey vodi plyiva riba: that's the heart of the matter (literally: that's the water a fish swims in); odnyimats she yak riba na sukhim: to try hard (literally: strive for water like a fish on dry soil); 
tsvenka yak riba: it is easy to catch him (literally: he can be caught as a fish); od hlavi riba shmerdzi: the problems start at top (literally: a fish starts to smell from its head).

SOKOL - oko sokolovo: an eagle s's eye (a falcon's eye).

SLON - pravits z mukhi slona: to make a mountain out of a molehill (literally: to make an elephant out of a fly).

SHVINYA - piyani yak shvinya: as drunk as a fish, as drunk as a billed owl (literally: as drunk as a pig); nye chuval ya z tobu shvinyi: we are not that close (or: we are not on an equal footing; literally: I did not watch over pigs with you); shvin 'ski obichay: indecent behaviour (literally: pig's habit); oblyech shvinyu do zlata, a vona poydze do blata: he can not change (literally: even if a pig wore clothes made of gold it would go into mud); tsaha she yak shvin'ski chereva: he walks slowly (literally: he drags his feet as pig's guts drag); nashey shvinyi prashe: our man (literally: our swine`s pig).

TASHCHOK - lyepshe tashchok u ruki yak holub na dreve: a bird in the hand is worth two in the bush (literally: a bird in the hand is better than a pigeon in the tree); nyich mu nye khibi lyem tashche mlyeko: he has everything (literally: he lacks nothing but sparrow`s milk); dze she tashchok lyahnye tam ho nazad tsahnye: a man always becomes homesick (literally: a sparrow always wants to go back to the place where it lays eggs).

TUZOK - yomu tuzok a mnye prepilku: you gave the bigger and the better to him (literally: a bustard to him and a quail to me).

USHA / VSHA - tsikho ye yak usha /vsha u khrasti: he is as quiet as a mouse (literally: he is as quiet as a louse in crust).

VIDRA - Rusin yak vidra: a Rusin is a resourceful person (literally: a Rusin is like an otter).

VOL - von vol: he is an ox ("stupid person"); robits yak vol: to work like a horse (literally: to work as an ox); yests yak vol: to eat too much (literally: to eat as an ox); dats dakomu yak volovi: to give somebody too much to eat (literally: to give somebody to eat as an ox); preysts yak vol: to pass by someone without greeting (literally: to pass by like an ox); chezhko tomu domu (domovi) dze rozkazuye krava volovi: it is bad for a house in which a woman commands (literally: it is bad for a house in which a cow commands an ox).

VOVK / FARKASH - hladni yak vovk: as hungry as a wolf; buts hladni yak vovk: to have a wolf in the stomach; vovk (farkash) shersts menya, alye norov nyigda: a wolf changes its appearance but never its character; vovk u ovchey skori: a wolf in sheep's clothing; budzits vovka khtori shpi: to wake a sleeping wolf; zverits ovtsi vovkovi: to have no confidence in someone (literally: to commit sheep to wolf's care); patrits yak (zbeshnyeti) vovk: be very angry (literally: to look like a mad wolf). 
VRANA - bila vrana: black sheep; vrana vrani oko nye vidzhubnye: people of the same kind will not harm themselves (literally: a crow will not peck an eye out to another (row).

ZAYATS - boyazhlyivi yakzayats: as timid as a hare; zabits naraz dva zayatsi: to kill two birds with one stone (literally: to kill two rabbits with one shot); $\mathrm{u}$ tim lyezhi zayats: that's the heart of the matter (literally: that is where a rabbit lies); zayacha dusha (shertso): real coward (rabbit's soul or heart).

ZHABA - zhabu nye treba honyits do vodi: it is easy to persuade him (literally: you do not have to drive a frog into water); klyipka yak zhaba u mutlyanki: he blinks the eyes (literally: he blinks like a frog in mud); nye modlyel she dyido babi nye budzem she ya yedney zhabi: you are not worthy of begging (literally: a grandpa did not beg grandma and I shall not beg a frog); zhimni yak zhaba: he is a cold person (literally: he is as cold as a frog); naduti yak zhaba: he is full of conceit (literally: he has become swollen as a frog).

\section{Result Analysis}

We have inventoried 190 Rusin idioms containing names of animals or parts of animals. 54 names of animals are included in the Rusin idioms. The most frequent ones are: pes (dog) - in 23 idioms; krava (cow) - in 11; riba (fish) - in 9; kon '(horse) and magarets (donkey) - in 8; tselye (calf), kura (hen), mish (mouse), mukha (fly) and vovk (wolf) - in 7; shvinja (swine) and vol (ox) in 6; ahnets / baranche / yahnyatko (lamb), machka (cat), ovtsa (sheep), ptitsa (bird), zhaba (frog) - in 5; buyak (bull), kache (duckling), and zayac (rabbit) in 4 etc. Each animal included in Rusin idioms present a common reference point that in time triggered the same association in the minds of native speakers and gives a piece of information of their experience.

There are 46 English counterparts containing the same animal names: wolf and lamb - 5 times; dog and fish - 4 times; horse, sheep and bird 3 times; cat and mouse - 2 times; bull, duckling, cow, crocodile, swallow, swan, fox, lion, monkey / ape, mule, fly, wasp / hornet, parrot, bee, pig, ox and hare - once. Some counterparts, such as those with wolf, lamb, dog and fish are identical (for ex. vovk u ovchey skori: a wolf in sheep s clothing; vadza she yak pes i machka: to fight like cats and dogs; yak riba u vodi: like a fish in water; zhertvene yahnyatko: sacrificial lamb). This almost perfect equivalency points to similar life experience that the speakers of Rusin and English shared in the past.

There are 20 English counterparts containing different animal names. Only fish appears three times; fish conveys the meanings "drunk" (< tselye),"quiet" (< riba) and "free" (< ptitsa). Bee, bird and mouse appear 
twice. Bee is used instead of "bug" and "worm" in somebody's head, bird is used instead of "sparrow" and "fly", and mouse instead of "fish" and "louse" conveying the meaning "quiet". The following animal names are used only once: buffalo, owl, mule, pig, dog, bear, mouse, eagle, horse.

There are 124 English counterparts not containing animal names. In these cases the counterparts convey the basic meanings of Rusin idioms. Literal translations of Rusin idioms have been provided in order to present their structure.

Animals in idioms of both languages often embody particular features, for ex. dogs represent people who are faithful or people who have a hard life since they are chained and depend on their masters; sheep represent stupid and naive persons; pigs are dirty and unpleasant; wolves are dangerous and evil; bees are hard-working; rabbits are fast and afraid; foxes are cunning etc.

\section{Conclusions}

Out of 190 Rusin idioms containing names of animals or parts of animals 46 English counterparts contain the same animal names, which makes $24.2 \%$ (or about one fourth) of the research corpus, and 20 English counterparts contain different animal names, which makes $10.5 \%$ (or about one tenth) of the research corpus. Generally speaking, English counterparts of Rusin animal idioms which do not exhibit animal names make two thirds of the research corpus. The use of different terms to express the same things is mostly determined by the cultural difference between the Rusin and the English societies.

We believe that this kind of research is very helpful for translaters into English and translaters into the Bachka-Srem Rusin. We also believe that the contrastive analysis has enabled students to be aware of similarities and differences in Rusin and English animal idioms to a great extent. Idioms of a language are not easy to master and further research is needed.

\section{REFERENCES}

Baker, M. \& Saldahna, G. (eds) (2011) Routledge Encyclopaedia of Translation Studies. London; New York: Routledge.

Baron, N. (2001) Alphabet to Email: How Written English Evolved and Where It's Heading. London: Routledge.

Benson, M. (1977) Srpskohrvatsko-engleski rechnik [Serbocroatian-English Dictionary]. Belgrade: Prosveta. 
Crystal, D. (2001) Language and the Internet. London: Cambridge University Press.

Fejsa, M. (1990) Angliyski elementi u ruskim yaziku [English Elements in the Rusin Language]. Novi Sad: Ruske slovo.

Fejsa, M. (2010) Nova Srbiya i nyena rusinska manyina / Nova Serbiya i yey ruska menshina [The New Serbia and Its Rusin Minority]. Novi Sad: IK Prometey \& KPD DOK.

Hornby, A. (1977) Oxford Advanced Learner's Dictionary of Current English. Oxford University Press.

Ivanovska B. \& Groszler,A. (2011) Animal Idioms In German and Their Macedonian Equivalents. In: Tochanats D. \& Gudurich S. (eds) Primenyena lingvistika danas - izmedyu teoriye i prakse. Novi Sad: Drushtvo za primenyenu lingvistiku Srbiye, Filozofski fakultet u Novom Sadu \& Filoloshki fakultet u Beogradu. pp. 27-36.

Koller, W. (1979) Einführung in die Übersetzungswissenschaft. Heidelberg: Quelle and Meyer.

Panou, D. (2013) Equivalence in Translation Theories: A Critical Evaluation. Theory and Practice in Language Studies. 3 (1).pp.1-6.DOI: 10.4304/tpls.3.1.1-6

Ramach,Yu.,Fejsa, M. \& Medyeshi,H.(1995) Srpsko-rusinski rechnik/Serbskoruski slovnyik [Serbian-Rusin Dictionary]. Vol. 1. Novi Sad: Univerzitet u Novim Sadze - Filozofski fakultet - Katedra za ruski yazik i literaturu \& Druzhtvo za ruski yazik i literaturu.

Ramach,Yu., Fejsa, M. \& Medyeshi, H. (1997) Srpsko-rusinski rechnik/Serbskoruski slovnyik [Serbian-Rusin Dictionary]. Vol. 2. Belgrade: Zavod za uchebnyiki i nastavni sredstva, Univerzitet u Novim Sadze - Filozofski fakultet - Katedra za ruski yazik i literaturu \& Druzhtvo za ruski yazik i literaturu.

Ristich, S., Simich,Zh. \& Popovich V. (1974) An English-Serbocroatian Dictionary/Entsiklopediski englesko-srpskohrvatski rechnik. Vol. I-II. Belgrade: Prosveta.

Ramach, Yu. (2002) Gramatika ruskoho yazika [Grammar of the Rusin Language]. Belgrade: Zavod za udzhbenike i nastavna sredstva.

Ramach, Yu., Timko-Dyitko, O., Medyeshi, H. \& Fejsa, M. (2010) Rusko-serbski slovnyik / Rusinsko-srpski rechnik [Rusin-Serbian Dictionary]. Novi Sad: Univerzitet u Novim Sadze - Filozofski fakultet - Katedra za ruski yazik i literaturu \& Zavod za kulturu voyvodyanskih Rusnacokh.

Varga,A. \& Groszler,A. (2008) Animal Idioms and Their Romanian Equivalents. Lucrări ştiințifice. 40 (3). pp. 369-373.

Mikhaylo Feysa - University of Novi Sad (Serbia).

Фейса Михайло - доктор лингвистических наук, профессор кафедры русинского языка и литературы философского факультета университета Нового Сада (Сербия).

E-mail: fejsam@gmail.com 